\title{
Bioedusiana
}

Blölogy

http://jurnal.unsil.ac.id/index.php/bioed

DOI: https://doi.org/10.37058/bioed.v6i2.4280

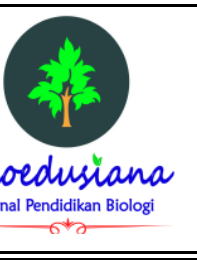

\section{Tingkat Pengetahuan Sekaa Teruna Terhadap Tanaman Upakara Hindu}

\section{Sekaa Teruna's Level of Knowledge of Hindu Upakara Plants}

\author{
I Made Sudiana ${ }^{1}$, I Ketut Surata ${ }^{2}$, Vita Meylani ${ }^{3 *}$ \\ 1,2 Program Studi Pendidikan Biologi, IKIP Saraswati, J1. Pahlawan No. 2, Tabanan, Bali, 82121, \\ Indonesia \\ ${ }^{3}$ Jurusan Pendidikan Biologi, FKIP, Universitas Siliwangi, Jln. Siliwangi No. 24, Tasikmalaya, Jawa \\ Barat 46115, Indonesia
}

\begin{abstract}
Abstrak
Sekaa Teruana (ST) sebagai generasi muda penerus adat budaya dan agama Hindu perlu mempunyai pengetahuan tentang tanaman upakara yang banyak digunakan dalam ritual keagamaan Hindu. Tingkat pengetahuan ST dalam mempersiapkan sarana dan mewujudkan bentuk upakara lebih baik. ST juga memiliki kesadaran untuk ikut menjaga kelestarian tanaman upakara. Telah dilakukan penelitian pada Sekaa Teruna (ST) di Desa Adat Sanggulan dan Desa Adat Tengkudak, untuk mengetahui tingkat pengetahuannya tentang tanaman upakara. Penelitian yang bersifat eksploratif menggunakan metode kuisioner untuk mengumpulkan data. Jenis kuesioner yang digunakan berupa kuesioner campuran terdiri dari 17 pernyataan/pertanyaan tertutup dan 8 pertanyaan terbuka. Data hasil isian kuisioner dianalisis secara deskriptif kualitatif dengan uji-t. Hasil penelitian menunjukkan yaitu tingkat pengetahuan ST Desa Adat Sanggulan sebesar 67,48 (cukup tinggi), dan ST Desa Adat Tengkudak sebesar 70,52 (cukup tinggi). Tingkat pengetahuan kedua ST berbeda tidak nyata (non signifikan) berdasarkan hasil uji-t pada taraf signifikasi $5 \%$ dan df 54. Dapat disimpulkan bahwa wilayah tempat tinggal yang dikotomis antara perkotaan dan pedesaan, tingkat keanekaragaman jenis tanaman upakara yang berbeda, tingkat pendidikan, jenis kelamin yang berbeda tidak berpengaruh langsung terhadap tingkat pengetahuan ST terhadap tanaman upakara.
\end{abstract}

Kata kunci: Hindu; Sekaa Teruna; Tanaman Upakara

\begin{abstract}
As the younger generation of Hindu cultural and religious practices inheritors, Sekaa Teruana (ST) must be knowledgeable about upakara plants, which are commonly employed in Hindu religious rites. ST's level of expertise in setting up facilities and putting up excellent ceremonies. ST is also conscious of the need of contributing to the preservation of upakara plants. To establish the amount of knowledge of upakara plants, research was conducted on Sekaa Teruna (ST) in Sanggulan Traditional Village and Tengkudak Traditional Village. The data for this exploratory study was gathered through the use of a questionnaire. A hybrid questionnaire with 17 closed statements/questions and 8 open items was employed. The $t$-test was used to assess the data from the questionnaires both descriptively and qualitatively. The ST Sanggulan Traditional Village's level of knowledge was 67.48 (sufficient), whereas the ST Tengkudak Traditional Village's level of knowledge was 70.52. (High enough). Based on the findings of the t-test at a significance level of 5\% and df 54, the level of knowledge of the two STs is not statistically different (non-significant). It can be inferred that the level of variety of different varieties of upakara plants, education level, and species different sexes have no direct effect on the level of ST knowledge of upakara plants.
\end{abstract}

Keywords: Hindu; Sekaa Teruna; Upakara Plants

Article History

Received: October 12 ${ }^{\text {nd }}, 2021$; Accepted: December 30 $0^{\text {th }}, 2021$; Published: December 31 $1^{\text {st }}, 2021$

Corresponding Author*

Vita Meylani, Jurusan Pendidikan Biologi, FKIP, Universitas Siliwangi, vibriovita@unsil.ac.id 


\section{PENDAHULUAN}

Seiring dengan meningkatnya kesejahteraan dan pemahaman masyarakat Hindu Bali tentang esensi ajaran Agama Hindu dalam bentuk Bakti Marga (jalan berbuat, berkarya), kegiatan ritual/upacara keagamaan juga semakin meningkat. Peningkatannya baik secara kuantitas maupun kualitas, hamper merata di seluruh Bali (Budiasih, 2019). Konsenkuensi terhadap peningkatan kegiatan ritual/upacara keagamaan yang terjadi membutuhkan banyak jenis tanaman sebagai sarana upakara banten (sesajen/persembahan). Jenis tanaman yang digunakan sebagai sarana upakara banten adalah jenis tanaman yang memiliki nilai spiritual berdasarkan aspek kesucian, makna filosofis teologis (simbol-simbol Ketuhanan), mitologi dari sarana-sarana tersebut serta aspek-aspek lain yang mendasari keyakinan umat dalam melaksanakan upacara yadnya (Armaeni, 2018). Organ tanaman yang digunakan sebagai sarana upakara, mulai dari akar, batang, daun, bunga, buah dan juga biji. Beberapa jenis tanaman upakara yang digunakan daunnya yaitu janur, daun alang-alang, sirih, dapdap, andong, lontar, pandan (Adiputra, 2017). Beberapa jenis bunga yaitu bunga teratai, kamboja, kenanga, cepaka, ratna, pacar air, dan bunga lainnya. Bagian buah yang digunakan dibedakan menjadi 3 yaitu phala gantung (misalnya, buah kelapa, pisang, mangga, jeruk, apel, d11), phala bungkah (umbi-umbian, misalnya ketela rambat, umbi talas) dan phalawija (misalnya, kacang merah, jagung,) (Sudiasa, 2014).

Dalam memenuhi kebutuhan terhadap tanaman upakara, diperlukan sedikit pengetahuan tentang habitus, struktur morfologis, habitat, dan benrtuk hidup tanaman tersebut. Sehubungan dengan itu, perlu dilakukan kajian tinggkat pengetahuan masyarakat Hindu Bali terhadap tanaman upakara, baik pengetahuan makna filosofis, fungsi, habitus, habitat, dan morfologis tanaman. Kajian ini penting, karena tingkat pengetahuan tentang tanaman upakara berpengaruh terhadap ketepatan jenis tanaman yang dicari (Puspa et al., 2019). Mengingat, tanaman upakara yang digunakan sarana upakara banten tidak boleh salah. Kesalahan atau ketidaktepatan tanaman upakara yang digunakan berdampak terhadap keberhasilan, kelancaran, dan kesucian dari upacara yang dilaksanakan.

Kajian tingkat pengetahuan masyarakat Hindu Bali terhadap tanaman upakara dilakukan pada Sekaa Teruna (ST), yaitu organiasi pemuda pada setiap Desa Adat dan Banjar Adat (Mahendra, 2016). Secara sosiologis dan praktis, generasi muda adalah anggota atau pribadipribadi yang masuk dalam kelompok itu memiliki pengalaman yang sama, khususnya peristiwa besar yang dialami secara serentak oleh seluruh masyarakat (Sumantri, dkk, 2019). Peranan Sekaa Teruna bagi generasi muda Hindu adalah sebagai wadah untuk menyalurkan dan mengembangkan kreatifitas, sebagai ujung tombak pengenalan dan pelestarian budaya, serta menjaga keajegan Budaya Bali (Ariyoga, 2019).

Pemilihan responden ST, karena mereka adalah generasi muda sebagai pewaris dan penerus keberadaan keyakinan Hindu. Melalui kajian ini, diperoleh gambaran utuh tentang 
pengetehuan SK terhadap tanaman upakara dengan segala aspek filosofis, fungsi, dan morfologis tanaman. Hal ini menjadi sangat urgen untuk diketahui, mengingat dewasa ini keberadaan tanaman upakara semakin langka dan sulit dikenali oleh generasi muda/ST sehingga berpotensi hilangnya pengetahuan luhur tradisional (kearifan lokal) tentang tanaman upakara. Hasil Kajian tingkat pengetahuan ST terhadap tanaman upakara dapat digunakan sebagai acuan untuk melakukan intervensi guna meningkatkan pengetahuannya. Sekaa Teruna dengan tingkat pengetahuan rendah sampai sedang diberikan pemebelajaran, pelatihan, dan praktik pengenalan tanaman upakara. Sekaa Teruna dengan tingkat pengetahuan cukup sampai tinggi diberikan penguatan dan dijadikan sebagai pendamping dalam kegiatan tersebut. Dengan cara seperti ini, terjadi pengimbasan pengetahuan antar ST, sehingga bentuk jalan Bakti Marga dalam keyakinan Hindu melalui kegiatan upacara keagamaan menjadi semakin berkualitas.

\section{METODE}

Penelitian ini adalah penelitian eksploratif, yaitu penelitian awal dari suatu penelitian yang sifatnya sangat luas (Yoga, 2020), dengan tujuan untuk mengetahui tingkat pengetahuan ST tentang tanaman upakara. Populasi sekaligus sampel dalam penelitian ini adalah semua pengurus sekaligus anggota dan anggota ST baik laki maupun perempuan. Semua populasi digunakan sebagai sampel, meningat jumlah ST di Desa. Adat Sanggulan Kecamatan Kediri Kabutapen Tabanan (wilayah perkotaan) dan Desa Adat Tengkudak, Kecamatan Penebel, Kabupaten Tabanan (wilayah pedesaan), tidak terlalu banyak. Sekaa Teruna Desa Adat Sanggulan sebanyak 40 orang (Data ST Desa Adat Sanggulan, 2020) dan Desa Adat Tengkudak 60 orang (Data ST Desa Adat Tengkudak, 2020). Selain jumlah ST yang tidak banyak, penetapan semua populasi sebagai sampel, juga didasarkan pada asumsi rata-rata tingkat pendidikan yaitu tamat SMA/SMK. Hanya ada beberapa yang tamat Diploma dan Strata 1. Dengan demikian, maka dapat diasumsikan bahwa semua sampel memiliki pengetahuan awal setara tentang tanaman upakara.

Pemilihan lokasi penelitian yang bersifat dikotomis, yaitu wilayah perkotaan dan pedesaan, bertujuan untuk melihat apakah terdapat perbedaan pengetahuan pada kedua ST tersebut. Mengingat di kedua wilayah tersebut tingkat keanekaraman hayati $(\mathrm{KH})$ tanaman upakaranya berbeda. Asumsinya bahwa dengan $\mathrm{KH}$ berbeda, pengetahuan ST tentang tanaman upakara juga berbeda.

Data tentang pengetahuan ST terhadap tanaman upakara, dikumpulkan dengan menggunakan kuisioner. Kuesioner yang digunakan sebanyak 25 butir, 17 butir berupa pertanyaan yang bersifat tertutup, dan 7 butir berupa pertanyaan terbuka mencakup beberapa indikator yang tercantum pada Tabel 1. 
Tabel 1. Kisi-kisi Kuesioner

\begin{tabular}{ll}
\hline \multicolumn{1}{c}{ Indikator } & \multicolumn{1}{c}{ Nomor Soal } \\
\hline Istilah tanaman upakara & 1,2 \\
Jenis tanaman upakara & $3,4,5,6,7,9,20$ \\
Cara mendapatkan tanaman upakara & 8 \\
Keterlibatan dalam menyiapkan upakara & $10,11,12$ \\
Makna filosofis tanaman upakara & $13,14,15,16,17$ \\
Pelestarian Tanaman Uapkara & $18,19,21,22$ \\
Pengetahuan dan Motivasi Pelestarian tanaman upakara & $23,24,25$ \\
\hline
\end{tabular}

Penyebaran kuisioner dilakukan secara terpusat dengan mengundang semua anggota ST. Pengisian kuisioner dilakukan di Balai Desa Adat masing-masing dan diawasi langsung. Sekaa Teruna Desa Adat Sanggulan pengisian kuisioner Desa Adat Tengkudak, 19 Januari 2020, sedangkan pengisian kuisioner untuk ST Desa Adat Sanggulan pada 9 Pebruari 2020.

Data yang terkumpul dianalisis secara deskriptif kuantitatif melaui perhitungan standar deviasi dan uji-t. Pada 17 butir kuisioner tertutup diberikan rentang skor dari 1 - 5 (1 artinya tingkat pengetahuan sangat rendah, 2 artinya rendah, 3 artinya cukup, 4 artinya tinggi, dan 5 artinya sangat tinggi), sedangkan 8 butir pertanyaan tebuka dinilai dari kualitas jawaban responden. Sangat berkualitas skor 5, berkualitas 4, cukup 3, kurang 2, tidak berkualitas 1 . Skor yang didapat selanjutnya dikonversi menjadi tingkat pengetahuan dari sangat rendah sampai sangat tinggi sebagai berikut (Nuryadi et al., 2017).

$$
\begin{aligned}
\mathrm{MI}+1,5 \mathrm{SDI} \leq \mathrm{X} & \text { Sangat tinggi } \\
\mathrm{MI}+0,5 \mathrm{SDI} \leq \mathrm{X}<\mathrm{MI}+1,5 \mathrm{SDI} & \text { Tinggi } \\
\mathrm{MI}-0,5 \mathrm{SDI} \leq \mathrm{X}<\mathrm{MI}+0,5 \mathrm{SDI} & \text { Cukup tinggi } \\
\mathrm{MI}-1,5 \mathrm{SDI} \leq \mathrm{X}<\mathrm{MI}-0,5 \mathrm{SDI} & \text { Kurang } \\
\mathrm{X} \leq \mathrm{MI}-1,5 \mathrm{SDI} & \text { Rendah }
\end{aligned}
$$

Dengan cara seperti ini, ke 25 butir kuisioner yang telah dijawab oleh responden dapat ditentukan tingkat pengetahuan masing-masing responden tentang tanaman upakara.

\section{HASIL DAN PEMBAHASAN}

Hasil

Tanaman upakara yang digunakan dalam kegiatan keagamaan adalah bagian-bagian tertentu saja seperti buah, daun, bunga. Tabel 2 menunjukkan beberapa tanaman upakara yang digunakan dalam ritual keagamaan. 
Tabel 2. Beberapa Jenis Tanaman Upakara Hindu

\begin{tabular}{|c|c|c|c|}
\hline \multirow[t]{2}{*}{ Nama Tanaman } & \multicolumn{2}{|r|}{ Klasifikasi } & \multirow{2}{*}{$\begin{array}{l}\text { Bagian yang digunakan } \\
\text { Buah }\end{array}$} \\
\hline & Kerajaan & : $\quad$ Plantae & \\
\hline & Divisi & : Spermatophyta & \\
\hline & Kelas & : Liliopsida & \\
\hline & Ordo & : Arecales & \\
\hline & Famili & : Arecaceae & \\
\hline & Genus & $: \quad \operatorname{Cocos}$ & \\
\hline & Spesies & : $\quad$ Cocos nucifera L. & \\
\hline & Nama daerah & : Kelapa gading & \\
\hline & Kerajaan & : $\quad$ Plantae & Daun \\
\hline & Divisi & : Magnoliphyta & \\
\hline & Kelas & : Magnoliopsida & \\
\hline & Ordo & : Urticales & \\
\hline & Famili & : $\quad$ Moraceae & \\
\hline & Genus & : $\quad$ Ficus & \\
\hline & Subgenus & : Conocycea & \\
\hline & Spesies & : $\quad$ Ficus benjamina $\mathrm{L}$. & \\
\hline & Nama daerah & : Beringin & \\
\hline & Kerajaan & : $\quad$ Plantae & Bunga \\
\hline & Divisi & : Spermatophyta & \\
\hline & Kelas & : Dicotyledoneae & \\
\hline & Ordo & : Nymphaeles & \\
\hline & Famili & : Nymphaeceae & \\
\hline & Genus & : Nymphaea & \\
\hline & Spesies & : $\quad$ Nymphaea caerulea $\mathrm{L}$. & \\
\hline & Nama daerah & : Bunga teratai & \\
\hline
\end{tabular}

Sekaa Teruna Desa Adat Sanggulan yang hadir memenuhi undangan pengisian kuisioner sebanyak 23 orang dari 40 orang anggota ST, sedangkan ST Desa Adat Tenggkudak yang hadir sebanyak 33 orang dari 60 anggota. Berdasarkan hasil isian kuesioner pada kedua ST, disajikan pada Tabel 3 dan 4 berikut.

Tabel 3. Hasil Isian Kuesioner Tingkat Pengetahuan ST Desa Adat Sanggulan

\begin{tabular}{lllllll}
\hline No. & Nama Responden & Jenis Kelamin & Usia & $\begin{array}{c}\text { Tingkat } \\
\text { Pendidikan }\end{array}$ & Nilai \\
\hline 1 & Responden 1 & L & 18 & SMA & 69 \\
2 & Responden 2 & L & 21 & SMA & 67 \\
3 & Responden 3 & L & 16 & SMA & 80 \\
4 & Responden 4 & L & 17 & SMA & 60 \\
5 & Responden 5 & L & 16 & SMA & 60 \\
6 & Responden 6 & L & 23 & SMK & 70 \\
7 & Responden 7 & L & 16 & SMK & 66 \\
8 & Responden 8 & L & 19 & SMA & 64 \\
9 & Responden 9 & L & 18 & SMA & 66 \\
10 & Responden 10 & L & 16 & SMA & 58
\end{tabular}




\begin{tabular}{llllll}
\hline No. & Nama Responden & Jenis Kelamin & Usia & $\begin{array}{c}\text { Tingkat } \\
\text { Pendidikan }\end{array}$ & Nilai \\
\hline 11 & Responden 11 & L & 23 & S1 & 81 \\
12 & Responden 12 & L & 17 & SMA & 69 \\
13 & Responden 13 & P & 21 & SMA & 70 \\
14 & Responden 14 & L & 17 & SMA & 59 \\
15 & Responden 15 & P & 17 & SMA & 70 \\
16 & Responden 16 & P & 22 & S1 & 62 \\
17 & Responden 17 & P & 23 & S1 & 67 \\
18 & Responden 18 & P & 22 & SMK & 76 \\
19 & Responden 19 & P & 24 & SMA & 66 \\
20 & Responden 20 & P & 22 & SMA & 73 \\
21 & Responden 21 & L & 17 & SMA & 60 \\
22 & Responden 22 & P & 22 & D4 & 75 \\
23 & Responden 23 & P & 20 & D3 & 64 \\
\hline & & & Total & $\mathbf{1 5 5 2}$ \\
\hline
\end{tabular}

Mengacu pada Tabel 3, dapat dijelaskan bahwa mayoritas anggota ST yang hadir adalah laki-laki yaitu sebanyak 14 orang, sedangkan perempuannya sebanyak 9 orang. Namun demikian, ternyata tingkat pengetahuan perempuan sedikit lebih tinggi dibangkan dengan laki-laki, yaitu rata-rata tingkat pengetahuan perempuan sebesar 69,22, sedangkanlaki-laki sebesar 66,36. Terlihat juga bahwa, tingkat pendidikan dan usia tidak secara langsung berpengaruh terhadap tingkat pengetahuan ST terhadap tanaman upakara. Responden 11 dengan pendidikan S1 mendapatkan total skor 81 pada kategori cukup tinggi (CT), tetapi Responden 16 dan 17 yang juga lulusan S1, hanya memperoleh skor sebesar masing-masing 62 dan 67 dengan kategori CT. Begitu juga dengan anggota Responden no 3 yang hanya lulusan SMA memperoleh total skor sebesar 80 dengan kategori CT.

Dari 23 anggota ST yang mengisi kuisioner, tidak ditemukan satupun yang memiliki tingkat pengetahuan sangat tinggi (ST), tetapi tidak ditemukan juga yang memiliki tingkat pengetahuan rendah (R) apalagi sangat rendah (SR). Semua anggota ST memiliki tingkat pengetahuan CT.

Tabel 4. Hasil Isian Kuesioner Tingkat Pengetahuan ST Desa Adat Tengkudak

\begin{tabular}{llllll}
\hline No. & Nama Responden & Jenis Kelamin & Usia & $\begin{array}{c}\text { Tingkat } \\
\text { Pendidikan }\end{array}$ & Jumlah Nilai \\
\hline 1 & Responden 1 & L & 20 & SMK & 58 \\
2 & Responden 2 & L & & & 68 \\
3 & Responden 3 & L & 18 & SMk & 75 \\
4 & Responden 4 & L & & SMP & 62 \\
5 & Responden 5 & L & 18 & SMK & 61 \\
6 & Responden 6 & L & 16 & SMK & 54 \\
7 & Responden 7 & L & 17 & SMK & 75 \\
8 & Responden 8 & L & 15 & SMK & 88 \\
9 & Responden 9 & L & 22 & S1 & 75
\end{tabular}




\begin{tabular}{llllll}
\hline No. & Nama Responden & Jenis Kelamin & Usia & $\begin{array}{c}\text { Tingkat } \\
\text { Pendidikan }\end{array}$ & Jumlah Nilai \\
\hline 10 & Responden 10 & L & 15 & SMP & 63 \\
11 & Responden 11 & L & 18 & SMK & 52 \\
12 & Responden 12 & L & 15 & SMP & 76 \\
13 & Responden 13 & L & 16 & SMA & 71 \\
14 & Responden 14 & L & 16 & STM & 52 \\
15 & Responden 15 & L & 22 & D1 & 74 \\
16 & Responden 16 & L & 15 & SMP & 93 \\
17 & Responden 17 & L & 19 & SMK & 83 \\
18 & Responden 18 & L & 23 & S1 & 91 \\
19 & Responden 19 & L & & SMA & 72 \\
20 & Responden 20 & L & 14 & SMP & 83 \\
21 & Responden 21 & L & 19 & SMK & 91 \\
22 & Responden 22 & L & 17 & SMA & 72 \\
23 & Responden 23 & L & 12 & SMP & 83 \\
24 & Responden 24 & L & 16 & SMK & 55 \\
25 & Responden 25 & L & 21 & D1 & 80 \\
26 & Responden 26 & L & 25 & SMK & 77 \\
27 & Responden 27 & L & 15 & SMK & 59 \\
28 & Responden 28 & L & 15 & SMP & 41 \\
29 & Responden 29 & P & 21 & SMK & 71 \\
30 & Responden 30 & P & 16 & SMA & 89 \\
31 & Responden 31 & P & 17 & SMA & 67 \\
32 & Responden 32 & P & 17 & SMA & 62 \\
33 & Responden 33 & P & 20 & SMK & 62 \\
\hline & & & & Total & $\mathbf{1 5 5 2}$ \\
\hline & & & Rata-rata & $\mathbf{6 7 , 4 8}$ \\
\hline
\end{tabular}

Berdasarkan hasil isian kuesioner dari ST Desa Adat Tengkudak (Tabel 4), terdapat perbedaan tingkat pengetahuan dengan ST Desa Adat Sanggulan (Tabel 3). Rata-rata total skor sebesar 70,52 pada ST Desa Adat Tengkudak lebih tinggi 3,04 daripada ST Desa Adat Sanggulan yang hanya sebesar 67,48. Hal berbeda lainnya dengan ST Desa Sanggulan yaitu bahwa total skor tertinggi justru diperoleh oleh Responden 11 dan 19 masing-masing sebesar 93 (ST) yang hanya lulusan SMK/SMA, mengalahkan total skor Responden 9 yang lulus S1 hanya mendapatkan skor sebesar 88 (ST) dan Responden 15 dan 25 yang tamat D1 hanya memperoleh skor masing-masing 76 dan 80 (CT)

Hal ini kembali menunjukkan bahwa tingkat pendidikan dan usia anggota ST tidak secara langsung berpengaruh terhadap tingkat pengetahuanya tentang tanaman upakara. Hal lain yang berbeda dari hasil isian kuesioner ST Desa Adat Tenggkudak yaitu ditemukan 4 anggota ST yang memiliki tingkat pengetahuan rendah sampai sangat rendah yaitu Responden 14 sebesar 52, Responden 17 juga 52, Responden 24 sebesar 55, dan Responden 28 sebesar 41. Hal seperti ini tidak ditemukan pada anggota ST Desa Adat Sanggulan. Semua anggota ST Sanggulan memiliki tingkat pengetahuan $\mathrm{CT}$. 
Kesamaan yang ditemukan dari hasil isian kuisioner ST Desa Adat Tengkudak dan ST Desa Adat Sanggulan yaitu, mayoritas anggota ST adalah laki-laki. Kesamaan lainnya yaitu bahwa tingkat pengetahuan kedua ST walau dengan rata-rata total skor berbeda, sama-sama berada dalam kategori cukup tinggi.

Berdasarkan Tabel 3 dan 4 dapat diagram rata-rata tingkat pengetahuan Sekaa Teruna dalam Gambar 1 berikut.

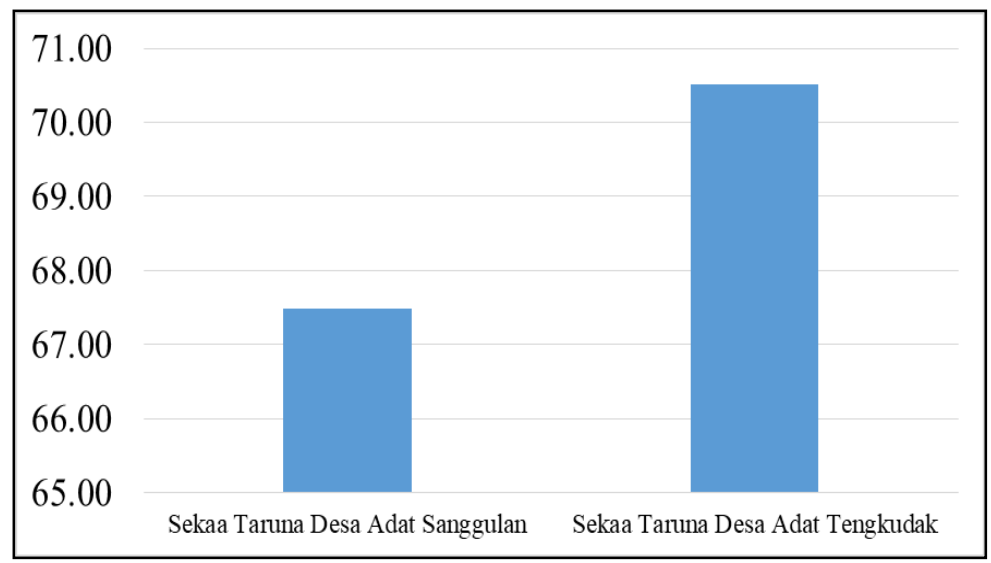

Gambar 1. Skor Rata-rata Tingkat Pengetahuan ST di Kedua Desa Adat

Mengacu pada Gambar 1, tampak bahwa rata-rata total skor tingkat pengetahuan ST di kedua Desa Adat cukup lebar. Hasil analisis uji statistic menunjukkan nilai t-hitung lebih kecil dibandingkan nilai t-tabel (Tabel 4), sehingga dapat dinyatakan bahwa tingkat pengetahuan ST terhadap tanaman upakara berbeda tidak nyata (non signifikan). Ini berarti bahwa, tidak ada perbedaan tingkat pengetahuan pada kedua ST terhadap tanaman upakara.

Tabel 5. Hasil Uji-t Tingkat Pengetahuan Sekaa Teruna

\begin{tabular}{lcccc}
\hline \multicolumn{1}{c}{ Sampel } & Jumlah Sampel & Df & t-hitung & t-tabel \\
\hline ST Desa Adat Tengkudak & 33 & 54 & 1,36 & 2,01 \\
ST Desa Adat Sanggulan & 23 & & & \multirow{2}{*}{} \\
\hline
\end{tabular}

\section{Pembahasan}

Hasil penelitian menemukan bahwa tingkat pengetahuan kedua kelompok ST di Desa Sanggulan dan Desa Tengkudak terhadap tanaman upakara berbeda tidak nyata (non signifikan), dapat dijelaskan sebagai berikut. Pengetahuan awal ST rata-rata tamat SMA/SMK, sehingga dapat dikategorikan berada pada level yang sama. Keterlibatan aktif ST dalam kegiatan ritual keagamaan Hindu dapat diasumsikan dalam kategori sedang, artinya tidak setiap ritual keagamaan yang dilaksanakan masyarakat, ST terlibat langsung. Temuan ini berbeda dengan penelitian sebelumnya yang dilakukan oleh Yanthi et al., (2020) yang menyebutkan bahwa tingkat pengetahuan masyarakat tentang makna filosofi dan fungsi tanaman di Desa Sanggulan dan Desa Tengkudak termasuk dalam kategori cukup tinggi. Akan tetapi, tingkat pengetahuan masyarakat 
di Desa Sanggulan dan Desa Tengkudak juga diketahui tidak berbeda secara signifikan terhadap pelestarian tanaman upakara (Noviyanti et al., 2020). Hasil ini, menunjukkan bahwa tingkat pengetahuan ST terhadap tanaman upakara tidak selalu berkorelasi dengan tingkat pendidikan.

Disisi lain, keterlibatan ST pada kegiatan ritual keagamaan yang dilaksanakan keluarga memiliki frekuensi yang cukup tinggi. Frekuensi keterlibatan ST dalam kegiatan ritual keagamaan yang dilaksanakan di lingkungan keluarga berimplikasi langsung terhadap pengetahuan ST tentang tanaman upakara. Semakin tinggi keterlibatannya dalam kegiatan upacara keagamaan, maka semakin banyak pengetahuan tentang tanaman upakara yang didapat, begitu sebaliknya. Hal tersebut didukung oleh penelitian yang dilakukan oleh Adnyadewi et al., (2020) bahwa tingkat pengetahuan generasi muda tentang tanaman upakara tidak berbeda secara signifikan bahkan dengan narasumber (stakeholder dalam kegiatan upacara keagamaan) tentang tanaman upakara. Mengingat dalam kegiatan ritual tersebut, ST diminta mencari tanaman upakara yang digunakan, praktik langsung menyediakan sarana upakara yang berasal dari tanaman dan sarana upakara lainnya. Sehingga kalau frekuensi keterlibatannya sangat berpengaruh terhadap pentehuan yang didapat. Oleh karena, pengetahuan tradisional termasuk pengetahuan tentang tanaman upakara didapat melalui praktik pengimbasan secara langsung dalam suatu kegiatan (Surata, et al., 2015). Pengetahuan tradisional termasuk tanaman upakara ini tidak diberikan dalam suatu lembaga pendidikan formal, termasuk tidak secara rinci diajarkan di sekolah dalam mata pelajaran Agama Hindu dalam semua jenjang satuan pendidikan. Sehingga dapat dipahami, tingkat pengetahuan ST pada kedua wilayah tersebut berbeda tidak nyata.

Perbedaan tidak nyata pengetahuan kedua ST terhadap tanaman upakara juga dapat dijelaskan pula bahwa kesemarakan kegiatan ritual keagamaan dikedua wilayah desa adat sama, mulai dari upacara Manusa Yadnya (ritual keagamaan dalam siklus hidup manusia), Dewa Yadnya (ritual keagamaan kepada Tuhan dengan segala manifestasinya), Pitra Yadnya (ritual keagamaan kepada manusia yang telah meninggal), dan Rsi Yadnya (ritual keagamaan kepada Pendeta). Melalui kesemarakan yang sama dalam kegiatan ritual keagamaan, maka frekuensi keterlibatan ST dapat diasumsikan sama.

Menurut skor rata-rata yang diperoleh dari kedua desa adat termasuk dalam kategori cukup tinggi (Gambar 1). Hal tersebut menunjukkan bahwa pengetahuan ST terhadap tanaman upakara masih dalam tataran yang wajar. Mengingat pengetahuan keagamaan terutama tentang tanaman upakara ini hanya diperoleh melalui pengimbasan melalui praktik secara langsung. Tidak melalui pendidikan formal seperti yang telah dijelaskan sebelumnya. Agar terjadi peningkatan pengetahuan ST sebagai generasi muda penerus Agama Hindu melalui jalan bakti marga (berbuat sesuai dengan ajaran agama Hindu), perlu dilakukan pembelajaran dengan melibatkan para pemangku kepentingan yaitu Parisada Hindu, kampus, ahli tanaman upakara, Pemangku 
(pemuput upacara yang sifatnya sedang sampai rendah), dan srati (orang yang ahli dalam pembuatan sarana upakara banten).

Tanaman upakara yang digunakan juga memiliki makna filosofis termasuk organ tanaman yang digunakan dalam kegiatan ritual keagamaan yang juga harus diketahui oleh ST. Diantaranya adalah kelapa gading ( $C$. nucifera L.) yang organ buahnya digunakan sebagai sarana upakara (Alukta, 2015). Kelapa gading digunakan dalam kegiatan upacara manusia yadnya, Rsi yadnya, Pitra yadnya, dan Dewa yadnya (Beratha, 2018). Pada saat upacara manusia yadnya buah kelapa gading digunakan pada banten durmanggala, sedangkan pada saat upacara metatah digunakan sebagai temoat potong gigi dan sarana melukat. Sedangkan pada saat upacara Rsi yadnya digunakan pada banten parayascita. Kelapa gading juga digunakan pada saat ngaben dan banten Diyus kamaligi dalam upacara Pitra yadnya. Selain itu, kelapa gading juga digunakan dalam upacara Dewa yadnya yaitu pada saat banten parayascita, banten mulang dasar bale, dan mulang dasar bangunan suci (Beratha, 2018). Secara filosofis, buah kelapa gading memiliki makna sebagai kekuatan toya (air) sukla, simbol kekuatan Tirta Mahamerta (Tirta Siwa), symbol kekuatan sad ripu atau sifat keraksaan simbol kekuatan Dewa Wisnu (Alukta, 2015). Oleh karena itu, buah kelapa gading sebagai simbol kekuatan air dan Dewa Wisnu banyak digunakan bpada berbagai kegiatan ritual keagamaaan.

Tanaman upakara yang lain adalah beringin ( F. benjamina L.), terutama bagian daunnya. Daun beringin digunakan sebagai sarana upakara Pitra yadnya khususnya upacara ngaben (Alukta, 2015). Beringin memiliki peran saat rangkaian upacara mamukur, yaitu penyucian atma agar terlepas dari badan halusnya (suksma sarira) berupa sifat-sifat manusia dan keinginannya sehingga bisa menyatu dengan Sang Pencipta menjadi Dewa Pitara (roh suci) (Beratha, 2018). Secara filosofis, beringin merupakan salah satu pohon yang telah mendapatkan penugrahan. Hal ini dikisahkan dalam Siwa Gama ketika perjalanan Bhagawan Salukat.dalam rangkaian tirtha yatra beliau mengantarkannya tiba di pesisir Negara Daha, yang mempertemukan Bhagawan Salukat dengan pohon beringin yang diberikan penugrahan. Selain itu, pohon beringin juga disebut sebagai pohon Siwa-Durga. Dengan kemultifungsian dari pohon beringin bagi umat Hindu khususnya di Bali. Pohon beringin dikatakan pula sebagai pohon surgawi, karena pohon beringin ini sebagai tempat rekreasi atau anjangsana para pitara-pitari yang sudah diaben. Sesuai dengan konsep ajaran Siwa di Bali, pohon beringin dikatakan sebagai pohonnya para-Dewa, khususnya Dewa Siwa. Tidak saja pitara-pitari yang menyenangi pohon beringin, makhluk lain juga menyukai pohon beringin karena memang memiliki kekuatan energi yang sangat besar. Secara fungsional dalam konsep Siwa di Bali, pohon beringin adalah tempat Dewa Siwa dan Dewi Durga beranjang sana yang ditemani para widyara-widyari (Alukta, 2015).

Tanaman upakara berikutnya adalah bunga teratai ( $N$. caerulea L.) yang digunakan sebagai sarana upakara/banten meliputi upakara pabayuhan, penglukatan, otonan, bunga hisasan 
canang, sarana persembahyangan, dan upacara ngaben (Beratha, 2018). Secara filosofi bunga Teratai dimaknai sebagai simbol keindahan yang tidak pernah luntur meskipun hidup di tempat yang kotor. Meskipun lingkungan tempat hidupnya kotor, tetapi Teratai selalu tampak indah dan menawan bahkan memberikan keindahan tambahan bagi lingkungan sekitarnya. Begitu juga kehidupan kita sebagai manusia. Manusia dilahirkan sebagai makhluk dengan keindahan dan kesempurnaan yang memerlukan keinginan atau hasrat untuk mencapai harta demi pencapaian sebuah tujuan. Tanpa keduanya perjalanan hidup manusia tidak akan pernah tercapai, tapi bukan lantas kita tenggelam diantara keduanya. Hasrat dan keinginan tetap kita jalani dengan kebaikan sehingga harta yang kita dapatkan bersumber dari kebaikan pula sehingga pada akhirnya akan memberikan suatu keindahan bagi lingkungan dan alam sekitarnya seperti bunga Teratai (Alukta, 2015).

Tidak dibelajarkannya tentang tanaman upakara melalui pendidikan formal atau non formal dan hanya mendasarkan pada pengimbasan pengetahuan melalui praktik secara langsung telah berimplikasi pada terjadinya komersialisasi dalam penyediaan sarana upakara banten dalam pelaksanaan ritual keagamaan Hindu di Bali. Komersialisasi ini terjadi karena selain kurangnya pengetahuan masyarakat termasuk ST tentang tanaman upakara dan sarana banten lainnya, juga disebabkan oleh kesibukan masyarakat dalam pekerjaan dibidang pariwisata (Yudari, 2018).

Guna menghindari terjadinya komersialisasi "agama” sekaligus untuk meningkatkan pengetahuan ST terhadap tanaman upakara dan mampu mewujudkan dalam bentuk simbolik sarana upakara (Puspa, et al., 2019), pembelajaran secara formal menjadi sangat penting dilakukan dengan melibatkan semua pemangku kepentingan, sebagaimana disebutkan sebelumnya. Bentuk pembelajaran yang dapat dilakukan yaitu problem based learning atau project based learning dengan lokasi pembelajaran di Wantilan Desa Adat masing-masing ST. Narasumber, pengajar dan pendamping adalah para pemangku kepentingan yang disebutkan di atas. Melalui kegiatan pembelajaran tersebut, dapat diyakini pengetahuan ST tentang tanaman upakara meningkat menjadi lebih tinggi. Dengan memahami makna filosofis, fungsi, bagian/organ tanaman yang digunakan sebagai sarana upakara banten, maka keimanan melalui kesemarakan ritual keagamaan menjadi semakin kuat di kalangan generasi muda.

\section{SIMPULAN}

Hasil penelitian menunjukkan bahwa tingkat pendidikan, jenis kelamin, dan usia ST tidak berpengaruh terhadap pengetahuan ST tentang tanaman upakara. Bahkan tempat tinggal ST (Kota atau Desa) dengan keanekaragaman tanaman upakara yang berbeda juga tidak berpengaruh terhadap pengetahuan ST tentang tanaman upakara. 


\section{REFERENSI}

Adiputra, I.N. (2017). Fungsi Buah dan Daun Tanaman dalam Budaya Bali sebuah Kajian terhadap Tanaman Upacara". Jurnal Bumi Lestari, 17(2). 118-125.

Alukta, Hindu. 2015. Makna Filosofi Kelapa Gading Dalam Hindu. Dalam : https://hindualukta.blogspot.com/2015/11/makna-filosofi-kelapa-gading-dalamhindu.html. Di akses 3 Desember 2019

Adnyadewi, N. M. A., Maduriana, I. M., \& Dwi, I. G. A. A. N. (2020). Studi Morfologi Dan Pengetahuan Generasi Muda Hindu Terhadap Tanaman Upakara Hindu Bali Di Kabupaten Tabanan. Jurnal Mahasisya Pendidikan, 2(1), 184-191.

Ambarani, D. P. L., Sudarsana, A. G. D., \& Sarwadana, S. M. (2016). Penempatan tanaman upakara sebagai elemen lunak taman pekarangan rumah ditinjau dari aspek filosofi budaya bali di kecamatan payangan, kabupaten gianyar, provinsi bali. Skripsi tidak diterbitkan). Universitas Udayana.

Ariyoga, I.N. (2019). Peran Organisasi Sekaa Teruna Teruni sebagai Media Komunikasi Kepemudaan Hindu. Prosiding Seminar Nasional "Kapitalisme Media dan Komunikasi Politik di Era Revolusi Industri 4.0". 113-121.

Beratha, Sutjiati,N.L., Rajeg, I. M., \& Sukarini, N. W. (2018). Fungi dan Makna Simbolis Pohon Beringin Dalam Kehidupan Masyarakat Bali. Jurnal Kajian Bali Volume 08,Nomor 02,Oktober 2018. Denpasar: UNUD. Di akses 3 Desember 2019.

Budiasih, M.N. 2019. "Perwujudan Keharmonisan Hubungan Antara Manusia dengan Alam dalam Upacara Hindu di Bali". Widya Duta Jurnal Ilmiah Ilmu Agama dan Ilmu Sosial Budaya, 14(1). 29-38.

Data Anggota Sekaa Teruna Desa Adat Sanggulan dan Desa Adat Tengkudak. 2020.

Kriswiyanti, E. (2012). Karakteristik Ragam Kultivar Kelapa (Cocos Nucifera L.) Yang Digunakan Sebagai Bahan Upakara Padudusan Alit Di Bali. Berita Biologi, 11(3), 321-327.

Mahendra, I.K.A. (2016). Optimalisasi Peran Sekaa Teruna Teruni (Organisasi Kepemudaan Berbasis Kearifan Lokal di Bali) dalam Mendukung Terwujudnya Sistem Tata Kelola Pemerintah Desa yang Baik melalui Gerakan "STT Kawal Desa". Fakultas Hukum Universitas Udayana.

Noviyanti, N. K., Sudiana, I. M., \& Sudirgayasa, I. G. (2020). Studi Analisis Keanekaragaman Hayati Dan Tingkat Pengetahuan Masyarakat Terhadap Upaya Pelestarian Tanaman Upakara Hindu Di Kabupaten Tabanan. Jurnal Mahasisya Pendidikan, 2(1), 177-183.

Nuryadi, dkk. (2017). Dasar-dasar Statistik Penelitian. Cetakan ke-1 Yogyakarta: Sibuku Media.

Puspa, I.A.T, dkk. 2019. "Komunikasi Simbolik dalam Penggunaan Upakara Yadnya pada Ritual Hindu". Widya Duta Jurnal Ilmiah Ilmu Agama dan Ilmu Sosial Budaya, 14(1). 20-28.

Putri, R. I., \& Walujo, E. B. (2013). Etnobotani Tumbuhan Penunjang Ritual/Adat Di Pulau Serangan, Bali. In Prosiding Seminar Nasional Prodi Biologi.

Sardiana, I. K., \& Dinata, K. K. (2010). Studi pemanfaatan tanaman pada kegiatan ritual (upakara) oleh umat Hindu di Bali. Jurnal Bumi Lestari, 10(1), 123-127.

Sudiasa. (2014). Acara Agama Hindu 3 Jenis Tanaman Upakara. http://mangdik62.blogspot.com/2014/01/acara-agama-hindu-3-jenis-tanaman.html Diakses pada 27 November 2019.

Sumantri. (2019). Generasi dan Generasi Muda. Modul 1. Pembinaan Generasi Muda. Jakarta.

Surata, I. K., Gata, I. W., \& Sudiana, I. M. (2015). Studi etnobotanik tanaman upacara Hindu Bali sebagai upaya pelestarian kearifan lokal. Jurnal Kajian Bali, 5(2), 265-284.

Yanthi, N. K. E., Oka, I. D. N., \& Surata, I. K. (2020). Studi Analisis Manfaat Dan Tingkat Pengetahuan Masyarakat Tentang Tanaman Upakara Hindu Di Kabupaten Tabanan. Jurnal Mahasisya Pendidikan, 2(1), 168-176.

Yoga, Dimas. (2020). Penelitian Eksploratif: Pengertian, Ciri, Tujuan, dan Contoh. https://www.ngeneki.com/penelitian-eksploratif/. Diakses pada Mei 2020. 